\title{
Implementasi Peraturan Pemerintah Nomor 53 Tahun 2010 Tentang Disiplin Pegawai Khususnya Aspek Jam Kerja Di Kabupaten Kutai Kartanegara ${ }^{1}$
}

\section{Implementation Regulation Government Regulation No.53 of 2010 about Employee Discipline Particular Aspect of Working Hours in Kutai Kartanegara Regency ${ }^{1}$}

\author{
Wildan Lutfi A, Mayahayati K \\ Pusat Kajian dan Pendidikan dan Pelatihan Aparatur III Lembaga Administrasi \\ Negara \\ Email :wildan_doank@yahoo.co.id
}

\begin{abstract}
This study aims to see the implementation of Government Regulation Number 53 Year 2010 about Government Apparatus Discipline in Kutai Kartanegara regency regarding the discipline on the use of working hours. Kukar district government has followed up this regulation by issuing Regional Regulation Number 46 Year 2013 about Enforcement of Civil Servants Discipline in Kutai Kartanegara regency. Based on interviews and questionnaires on the perception of civil servants in the Kutai Kartanegara regency, it can be concluded that in some local government units, the enforcement of rules related working hours disciplines have been optimized at the structural level, but still not up to the lower level. Understanding on the prohibitions of Government Apparatus Discipline has been predominantly known and understood by the majority of structural officials. Management to get permission to use work hours for personal use is still tolerable but has not been managed well, and additional revenue (TPP) were deemed to be highly related to the discipline of hours worked by employees and become a powerful instrument to encourage civil servants to be discipline and obeying the rules. Coaching employees to be able to behave professionally, improve capabilities and change his mind set against the additional revenue (TPP) and working hours.
\end{abstract}

Keywords: Discipline, working hours, the Government of Kutai Kartanegara Regency

\begin{abstract}
Abstrak
Kajian ini bertujuan untuk melihat implementasi PP 53 No 2010 Tentang Disiplin Pegawai di lingkungan Pemerintah Kabupaten Kutai Kartanegara pada aspek kedisiplinan terhadap jam kerja. Pemkab Kukar telah menindaklanjuti PP tersebut dengan menerbitkan Perbup No 46/2013 tentang Penegakan Disiplin PNS di lingkungan Kabupaten Kutai Kartanegara. Berdasarkan hasil wawancara dan pengumpulan kuisioner terhadap persepsi dari PNS di Pemkab Kutai Kartanegara, disimpulkan di beberapa SKPD, penegakan disiplin terkait aturan jam kerja telah optimal pada tataran struktural, namun masih belum maksimal dilaksanakan
\end{abstract}

1 Naskah di terima pada 29 November 2015, revisi pertama pada 14 Desember 2015, disetujui pada 16 Desember 2015 
hingga ke level bawah. Pemahaman terhadap larangan-larangan dalam aturan kedisiplinan telah secara dominan diketahui dan dipahami oleh sebagian besar pejabat struktural. Pengelolaan ijin terhadap penggunaan jam kerja untuk keperluan pribadi, masih ditoleransi, namun belum dikelola dengan baik dan TPP dianggap masih sangat berkaitan dengan disiplin jam kerja pegawai dan menjadi instrumen yang ampuh untuk mendorong pegawai taat pada aturan. Pembinaan pegawai agar mampu bersikap professional, meningkatkan kapabilitasnya dan merubah mind set-nya terhadap TPP dan jam kerja.

Kata Kunci : Disiplin, Jam kerja, Pemerintah Kabupaten Kutai Kartanegara

\section{A. PENDAHULUAN}

Peranan pegawai negeri sipil sebagai aparatur sipil negara dalam pelaksanaan kebijakan otonomi daerah memiliki peran yang sangat strategis. Salah satu peran strategisnya adalah mendorong perubahan internal untuk memaksimalkan kinerja pelayanan publik. Dibutuhkan keteladanan sikap dan prilaku yang melayani, termasuk kedisiplinan. Pelayanan membutuhkan ketepatan waktu, sebagaimana masyarakat menginginkan jasa pelayanan yang juga tepat waktu. Ketidaktepatan waktu pelayanan hanya akan meninggalkan ketidakpuasan bagi masyarakat yang pada akhirnya menimbulkan ketidakpercayaan masyarakat pada pemerintah daerah. Untuk mewujudkan sosok aparatur yang profesional sebagaimana yang diharapkan UU Nomor 5 Tahun 2013, menanamkan kedisiplinan tentulah bukan hal yang mudah. Selalu banyak hambatan dan permasalahan yang dihadapi. Sejak PP No. 53 tahun 2010 digulirkan kedisiplinan PNS masih rendah, Di media-media seringkali kita lihat, pada hari kerja setelah libur panjang, pimpinan daerah dan instansi terkait melakukan sidak di lingkungannya. Selain itu, razia bagi PNS yang berkeliaran atau duduk-duduk di kedai kopi pada saat jam kerja juga dilakukan oleh Pemerintah daerah.

"Hasil sidak pasca libur

lebaran yang dilakukan

di seluruh SKPD, UPT,

Kantor Lurah dan
Puskesmas di Kota Dumai, pegawai yang tidak hadir tanpa keterangan sebanyak 20 orang, izin 27 orang, dengan keterangan sakit 23 orang dan cuti 112 orang".

"Badan Kepegawaian Daerah (BKD) Sekadau bersama Inspektorat Sekadau melakukan inspeksi mendadak (sidak) kehadiran pegawai negeri sipil (PNS) di lingkungan SKPD. kehadiran pada hari pertama kerja setelah libur sekitar 90 persen".

"Penjabat (Pj) Bupati Kutai Kartanegara (Kukar) H Chairil Anwar didampingi Kabag Humas dan Protokol Setkab Kukar Dafip Haryanto melakukan inspeksi mendadak (Sidak) ke sejumlah $p$ e $r k a n t o r a n$ Dinas/Instansi dilingkungan Pemkab Kukar. Terutama yang berhubungan dengan pelayanan publik. Dari 7 SKPD yang dikunjungi terdapat 23 orang PNS diketahui cuti dan 14 
orang lainnya ijin, dan rara-rata kehadiran PNS 95 persen."

"Penerapan PP No. 53

Tahun 2010 Tentang

Disiplin Pegawai Negeri

Sipil (PNS) di Karimun

dikarenakan tingkat

disiplin PNS di Karimun

terbilang rendah di tahun

sebelumnya, Wabup

mengintruksikan Satuan

Polisi Pamong Praja

(Satpol PP) menggelar

razia bagi PNS yang

berkeliaran atau duduk di

kedai kopi di saat jam

kerja." (www. Tanjung

Pinang Post.com, 6

Januari 2014, diunduh

tanggal 20 Feb 2014)"

Bahkan, BKN Kanreg I Jawa

Tengah-DIY mengungkapkan dalam rapat koordinasi membahas evaluasi terhadap kinerja PNS, dikatakan hal-hal sebagai berikut:

a.Masih banyak PNS yang belum memahami ketentuan PP No. 53 tahun 2010.

b. Masih banyak pejabat yang menunggu perintah atasan untuk menindaklanjuti pelanggaran PNS di bawahnya.

c.Banyak pejabat yang masih menyerahkan atau menunggu tindakan yang akan diambil oleh pihak Inspektorat, sehingga peran aktif jemput bola dari pejabat sangat kurang.

d.Banyak PNS yang baru diberikan sanksi setelah tidak masuk kerja melebihi 46 hari. Padahal, dalam aturannya seorang pegawai yang tidak masuk kerja tanpa alasan yang jelas harus segera dijatuhi hukuman disiplin sesuai dengan tingkat pelanggaran yang ada (sejumlah hari yang telah ditinggalkan) tanpa harus menunggu sampai batas lebih dari 46 hari.
Fenomena-fenomena ini mengindikasikan Pemerintah masih punya 'pekerjaan rumah' untuk mendisiplinkan pegawainya. Implementasi PP No 53 Tahun 2010 secara umum masih belum optimal. Kutai Kartanegara dengan jumlah pegawai mencapai 16.639 pegawai terus berupaya meningkatkan kedisiplinan pegawainya. Kebijakan pembangunan daerah Gerbang Raja dengan salah satu misi adalah pencapaian target tata kelola pemerintahan yang baik, diantaranya melalui disiplin pegawai sebagai prasyarat profesionalisme PNS. Menyadari banyaknya pegawai di lingkungan Pemerintah Kabupaten Kutai Kartanegara, tentunya hal tersebut menjadi persoalan tersendiri. Tuntutan masyarakat yang menginginkan kemudahan, kecepatan, atau peningkatan 1 a y a $n$ a $n$ d a $\mathrm{k}$ i n e $\mathrm{r}$ j a pemerintah/aparaturnya serta kemajuan teknologi saat ini juga semakin meningkat, dibutuhkan aparatur yang kompeten dan professional dalam memberikan kinerjanya. Kajian ini bertujuan menganalisis impelementasi PP 53 Tahun 2010 serta faktor-faktor pendorong dan penghambat yang mempengaruhi implementasi PP 53 di Kutai Kartanegara.

\section{B. METODE PENELITIAN}

Kajian ini menggunakan pendekatan kuantitatif dan kualitatif. Pengumpulan data dilakukan secara purposive sampling, dan teknik pengolahan data dilakukan menggunakan aplikasi excel sederhana. Data diperoleh melalui penyebaran kuisioner kepada pegawai di lingkungan Pemkab Kukar serta wawancara (depth interview) dengan informan kunci, yakni Asisten I, BKD dan Inspektorat Pemerintah Kukar. Data sekunder digunakan hasil kajian sebelumya, jurnal serta data kepegawaian 
lainnya. Kajian ini secara purposive memilih lokus dengan sampel SKPD yang secara proporsional terhadap total jumlah SKPD dengan menetapkan 11 SKPD di lingkungan Pemerintah Kabupaten Kutai
Kartanegara. Adapun dari 9 SKPD yang ditetapkan, sejumlah 6 SKPD ditetapkan berdasarkan kriteria jumlah pegawai dengan klasifikasi Dinas, Badan dan Kantor. Sedangkan sejumlah 5 SKPD ditetapkan secara acak.

Tabel 1. Penetapan Sampel SKPD Pemerintah Kabupaten Kutai Kartanegara

\begin{tabular}{|l|l|}
\hline \multicolumn{1}{|c|}{ Berdasarkan jumlah pegawai } & \multicolumn{1}{|c|}{$\begin{array}{c}\text { Terkait langsung dengan } \\
\text { implementasi disiplin }\end{array}$} \\
\hline 1.Dinas Pendidikan & 1.Inspektorat \\
2.Dinas Sosial & 2.Badan Kepegawaian Daerah \\
3.Dinas Pendapatan Daerah & \\
4.Dinas Pemuda dan Olahraga & \\
5.Badan Ketahanan Pangan dan Penyuluhan \\
6.Badan Pelayanan Perijinan Terpadu
\end{tabular}

Responden ditetapkan proporsional dari seluruh jumlah pegawai di lingkungan Pemerintah Kabupaten Kutai Kartanegara, yaitu sejumlah 269 responden dengan taraf kesalahan 10\% berdasarkan table penetapan sampel Isaac and Michael (1981). Penyebaran responden dengan klasifikasi Dinas, Badan dan Kantor sesuai dengan jumlah SKPD yang telah ditetapkan.

Total pejabat struktural yang menjadi sampel kajian ini adalah sebanyak 101 orang, dengan rincian Eselon 2 yang mengisi kuisioner sebanyak 1 orang, Eselon 3 sebanyak 24 orang, dan Eselon 4 sebanyak 73 orang. Adapun sisanya sebanyak 3 orang tidak memberikan atau tanpa keterangan jabatan. Ditinjau dari tingkat pendidikan, pejabat struktural yang menjadi responden kajian ini paling banyak memiliki tingkat pendidikan diploma $(50 \%)$, diikuti tingkat pendidikan terakhir S1 sebanyak $30,11 \%$, S2 sebanyak $18,75 \%$, dan S3 sebanyak $1,14 \%$. Sedangkan dari sisi lama bekerja dalam jabatannya didominasi oleh durasi di bawah 5 tahun yakni sebesar 64,13\%, selanjutnya pejabat dengan durasi menjabat antara 5-10 tahun sebanyak $17,39 \%$. Berdasarkan informasi tersebut, meskipun pada tataran pimpinan tinggi (eselon 2) hanya diwakili oleh 1 responden, namun relatif secara proporsi jumlah dan penyebaran informasi yang didapatkan dapat mewakili pemahaman umum seluruh pejabat struktural di lingkungan Pemerintah Kabupaten Kutai Kartanegara.

Pejabat fungsional yang menjadi responden kajian ini berjumlah sekitar 172 orang, dimana 19 orang diantaranya adalah pejabat fungsional tertentu, sebanyak 140 orang adalah pejabat fungsional umum, dan sisanya 13 orang tidak memberikan keterangan posisi jabatannya. Responden-responden ini tersebar di SKPD-SKPD yang menjadi sampel kajian ini. Dari sisi lama bekerja, sebanyak $37,89 \%$ responden tersebut memiliki masa kerja antara 5-10 tahun, sedangkan lama bekerja diatas 11 tahun 
sebesar $25,47 \%$, dan sisanya yang bekerja dibawah 5 tahun sebesar $36,65 \%$. Pemahaman atau persepsi dari keseluruhan responden ini diharapkan dapat memberikan gambaran utuh terhadap implementasi PP No. 53 Tahun 2010 di lingkungan Pemerintah Kabupaten Kutai Kartanegara.

Tingkat pendidikan pejabat fungsional yang menjadi sampel penelitian ini secara lengkap dapat dilihat pada chart di bawah:

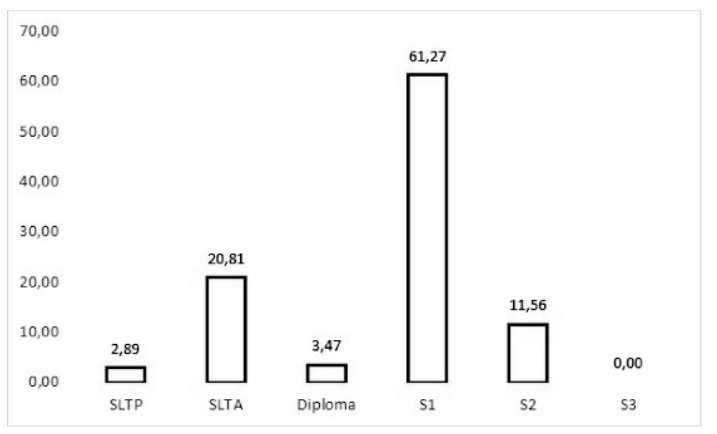

Gambar 1. Persentase Tingkat Pendidikan Responden Jabatan Fungsional Umum dan Tertentu

Sebagian besar responden kajian ini memiliki tingkat pendidikan S1 $(61,27 \%)$ dan tingkat pendidikan terendah adalah SLTP dengan persentase hanya 2,89\%. Jika dikelompokkan tingkat pendidikan Diploma, S1, dan S2 pada kategori pendidikan tinggi maka sebanyak $76,30 \%$ responden memiliki tingkat pendidikan pada kelompok pendidikan tinggi, sehingga informasi yang diberikan oleh responden pejabat fungsional ini relatif relevan untuk digunakan sebagai bahan analisis. Alur pikir pada kajian ini adalah:

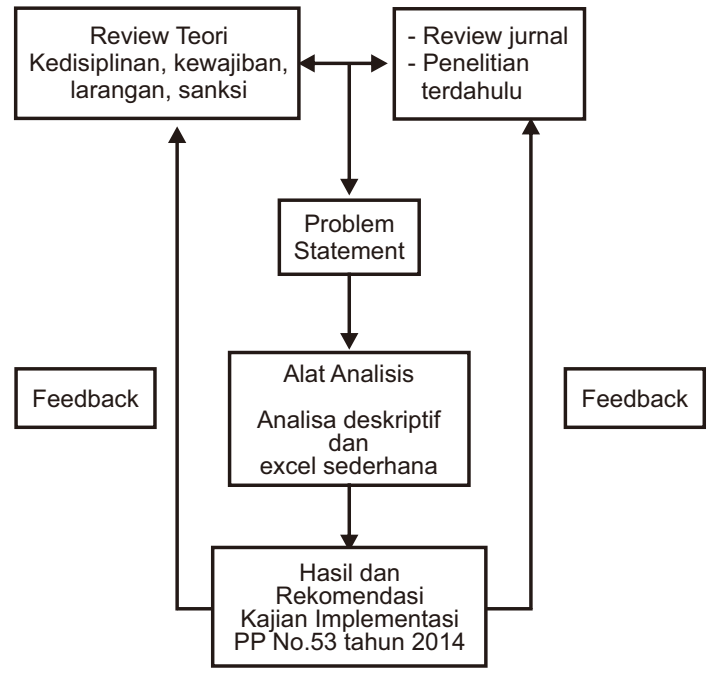

Gambar 2.

Bagan Alur Pikir Kajian Implementasi PP Nomor 53 Tahun 2010 tentang Disiplin Pegawai

\section{KERANGKA TEORI}

D i s i p 1 i n m e n u r u t Sastrohardiwiryo (2003:291) merupakan suatu sikap menghormati, menghargai, patuh dan taat terhadap peraturanperaturan yang berlaku, baik yang tertulis maupun tidak tertulis serta sanggup menjalankannya dan tidak menggelak untuk menerima sanksi-sanksinya apabila ia melanggar tugas dan wewenang yang diberikan kepadanya. Selaras dengan pengertian tersebut, Sutrisno (2009: 94) mendefinisikan disiplin pegawai sebagai perilaku seseorang yang sesuai dengan peraturan, prosedur kerja yang ada atau disiplin adalah sikap, tingkah laku dan perbuatan yang sesuai dengan peraturan dari organisasi baik tertulis maupun yang tidak tertulis. Pengertian lain dari disiplin, yaitu prosedur yang mengkoreksi atau menghukum karena melanggar peraturan atau prosedur (Simamora, 2004:610). 
Moekizat (2002: 356) membagi disiplin menjadi dua, yakni:

1. Self imposed discipline yaitu disiplin yang dipaksanakan diri sendiri. Disiplin yang berasal dari diri sesorang yang ada pada hakikatnya merupakan suatu tanggapan spontan terhadap pimpinan yang cakap dan merupakan semacam dorongan pada dirinya sendiri artinya suatu keinginan dan kemauan untuk mengerjakan apa yang sesuai dengan keinginan kelompok.

2. Command discipline yaitu disiplin yang diperintahkan. Disiplin yang berasal dari suatu kekuasaan yang diakui dan menggunakan cara-cara menakutkan untuk memperoleh pelaksanaan dengan tindakan yang diinginkan yang dinyatakan melalui kebiasaan, peraturan-peraturan tertentu. Dalam bentuknya yang ekstrim "command discipline" memperoleh pelaksanaannya dengan menggunakan hukum.
Disiplin dibutuhkan untuk tujuan organisasi yang lebih jauh, juga guna menjaga efisiensi dengan mencegah dan mengoreksi tindakantindakan individu dalam iktikad tidak baiknya terhadap kelompok, disiplin berusaha untuk melindungi prilaku baik dengan menetapkan respon yang dikehendaki (Sutrisno, 2009:92). Malayu S.P Hasibuan, (2003:193) dalam Elvira 2014, beberapa indikator kedisiplinan:"beberapa indikator kedisplinan diantaranya adalah: Tujuan organisasi dan kemampuan individu, Teladan Pimpinan, pengawasan melekat, balas jasa, Keadilan, sanksi hukuman, ketegasan, hubungan kemanusiaan". Ad apun karakteristik disiplin pegawai yang digunakan mengacu pada indikator yang dikemukakan oleh Hasibuan, yang dapat terlihat pada tabel blue print sebagai berikut:

Tabel 2. Blue Print Karakteristik Disiplin Pegawai

\begin{tabular}{|l|l|l|}
\hline NO & Indikator & Sub Indikator \\
\hline 1 & Tujuan dan Kemampuan & $\begin{array}{l}\text { - Tujuan Organisasi } \\
\text { - Kemampuan Pegawai }\end{array}$ \\
\hline 2 & Teladan Pimpinan & $\begin{array}{l}\text { Pimpinan mempunyai teladan yang } \\
\text { baik,jujur dan adil }\end{array}$ \\
\hline 3 & Balas Jasa & $\begin{array}{l}\text { Kompensasi dalam bentuk gaji, } \\
\text { tunjangan/ Insentif }\end{array}$ \\
\hline 4 & Keadilan & $\begin{array}{l}\text { Perlakuan sama terhadap semua } \\
\text { pegawai }\end{array}$ \\
\hline 5 & Pengawasan Melekat & $\begin{array}{l}\text { Mengawasi perilaku moral,sikap } \\
\text { kerja dan perilaku pegawai }\end{array}$ \\
\hline 6 & Sanksi hukuman & Berdasarkan PP 53 \\
\hline 7 & Ketegasan & $\begin{array}{l}\text { Berani bertindak tegas menerapkan } \\
\text { peraturan kepada pegawai yang } \\
\text { melanggar }\end{array}$ \\
\hline 8 & Hubungan Kemanusiaan & $\begin{array}{l}\text { Lingkungan dan suasana kerja } \\
\text { yang harmonis. }\end{array}$ \\
\hline
\end{tabular}

Sumber data: Hasibuan (2003) dalam Elfira (2014) 
Berlakunya UU No 5 Tahun 2014 tentang Aparatur Sipil Negara (ASN) mengubah paradigma tugas, pokok, dan fungsi (tupoksi) PNS menjadi pelaksana kebijakan publik, pelayan publik, serta perekat dan pemersatu bangsa. Tuntutan agar Aparatur Sipil Negara memiliki integritas, profesional, netral dan bebas, mampu menjadi aparatur sekaligus pelayan publik yang cekatan, dinamis, inovatif, dan kreatif dalam menyelenggarakan pelayanan publik bagi masyarakat, serta mampu menjalankan perannya sebagai unsur perekat persatuan dan kesatuan bangsa. Perbaikan mind set dan culture set ASN penting untuk menanamkan kedisiplinan dalam rangka perwujudan ASN yang profesional.

Dalam UU ASN, untuk menjamin terpeliharanya tata tertib dalam kelancaran pelaksanaan tugas, PNS wajib mematuhi disiplin PNS. Instansi Pemerintah wajib melaksanakan penegakan disiplin terhadap PNS serta melaksanakan berbagai upaya peningkatan disiplin. PNS yang melakukan pelanggaran disiplin akan dijatuhi hukuman disiplin. PP 53 tentang Disiplin PNS mendefinisikan Disiplin Pegawai Negeri Sipil sebagai kesanggupan Pegawai Negeri Sipil untuk menaati kewajiban dan menghindari larangan yang ditentukan dalam peraturan perundang-undangan dan/atau peraturan kedinasan yang apabila tidak ditaati atau dilanggar dijatuhi hukuman disiplin. Pelanggaran disiplin adalah setiap ucapan, tulisan, atau perbuatan PNS yang tidak menaati kewajiban dan/atau melanggar larangan ketentuan disiplin PNS, baik yang dilakukan di dalam maupun di luar jam kerja, dan hukuman disiplin adalah hukuman yang dijatuhkan kepada PNS karena melanggar peraturan disiplin PNS. Implementasi PP 53 terhadap kedisiplinan PNS di lapangan dipengaruhi oleh factor-faktor. Model George C. Edward III, (Wagiarti,
2013:16) menjelaskan empat variabel yang berpengaruh terhadap keberhasilan implementasi kebijakan, yaitu:

a. Komunikasi (communication), dimana transformasi informasi (transmisi), kejelasan informasi (clarity) dan konsistensi informasi (consistency) menjadi tiga unsur utama dalam proses informasi kebijakan.

b. Sumber daya (resources), dimana jumlah sumber daya harus mencukupi untuk melaksanakan kebijakan.

c. Disposisi (dispositions) atau sikap (attitudes), dimana terdapat tiga bentuk sikap atau respon implementator terhadap kebijakan, yaitu kesadaran pelaksana, petunjuk/arahan pelaksana untuk merespon tujuan kebijakan ke arah penerimaan atau penolakan, dan intensitas dari respon tersebut.

d. Struktur birokrasi (beureaucratic structure), dimana ada dua karakteristik yang utama yaitu prosedur kerja atau Standar Operating Procedures (SOP), dan fragmentasi.

Penelitian-penelitian terkait disiplin pegawai diantaranya dilakukan oleh Thahier terhadap PNS di lingkungan Sekretariat Daerah Provinsi Sulawesi Barat. Hasil penelitian menjelaskan bahwa kendala dalam peningkatan disiplin PNS adalah kurangnya profesionalisme dan tanggung jawab PNS dalam menyelenggarakan tugasnya, kurang tegasnya sanksi yang diberikan oleh pejabat yang berwenang serta lunturnya kedisiplinan PNS daerah. Listyaningsih yang mengkaji disiplin pegawai di Pemerintah Provinsi Banten mendapatkan bahwa responden mengidentifikasikan lemahnya penerapan reward dan punishment dalam memotivasi peningkatan kinerja pegawai, 
tidak meratanya 'kesejahteraan' antar SKPD, kurangnya ketegasan dan keteladanan pimpinan sebagai faktor yang mempengaruhi kinerja dan disiplin pegawai negeri sipil di Banten. Kurangnya ketegasan dan teladan pimpinan menjadi factor yang sering muncul sebagai penghambat implementasi disiplin PNS di daerah. Penelitian yang dilakukan Amantoto di Pemda Lampung menggali lebih dalam lagi dan menyayangkan bahwa kedisiplinan disini dipahami dalam konteks formal, yang diidentikkan dengan datang dan pulang tepat waktu, patuh terhadap atasan, menggunakan pakaian dinas, melaksanakan tugas sesuai dengan perintah, mematuhi hak dan kewajiban. Hal yang lebih mendasar dari disiplin sebenarnya adalah sebuah sikap kepatuhan terhadap peraturan yang berlaku yang didasarkan kepada kesadaran internal tanpa adanya sebuah paksaan baik berupa paksaan sistem ataupun personal. Penelitian Amantoto ini membuktikan bahwa hampir 80 persen PNS Di Pemda Lampung hanya memahami disiplin dari sisi formalnya saja. Menurutnya, hal ini akan menjadi persoalan jika dikaitkan dengan tren organisasi abad 21 yang menganggap penting sisi enterprenuership dan menjadikan pemerintah berorientasi kepada "pasar" memerlukan sisi inisiatif pegawai, di abad 21 pegawai tidak lagi ditempatkan pada posisi hanya menjalankan perintah tapi juga harus kreatif dalam memecahkan persoalan.

\section{HASILDAN PEMBAHASAN}

Penegakan disiplin pegawai bagi Pemkab Kukar bukanlah hal yang mudah, mengingat jumlah PNS yang ada saat ini sangat besar, yakni hampir 17.000 orang. Hal tersebut diperparah dengan penyebaran pegawai yang tidak merata, dimana sekitar $50 \%$ jumlah pegawai berada di ibu kota kabupaten, sehingga pengawasan terhadap disiplin pegawai menjadi terkendala. Menurut Kepala BKD Kukar, di tahun 2011, kedisiplinan pegawai Kukar masih kurang. Pegawai bekerja sesuai kebiasaan, tidak masuk kerja menjadi hal yang biasa, dan beberapa Kepala SKPD tidak menganggap sebagai tanggung jawabnya, sehingga hal ini terus berlangsung. Penegakan disiplin bagi hampir 17 ribu pegawai terus diupayakan Pemkab Kukar. Sosialisasi dalam rangka penegakan disiplin pun telah banyak dilakukan Pemkab Kukar. Di tahun 2012, Sekretariat DPRD telah melakukan sosialisasi PP ini di lingkungan internalnya, Sekretaris DPRD menyatakan untuk disiplin, tidak sekadar mengikuti apel pagi tapi disiplin di segala hal. Sosialisasi juga dilakukan di lingkungan Sekretariat Daerah, Sekkab juga menegaskan keikutsertaan apel pagi namun setelahnya pegawai yang bersangkutan pulang dengan alasan antar anak ke sekolah dan lainnya, bahkan ada yang turun siang, tidak boleh dilakukan". Selain sosialisasi mengenai PP 53/2010 ini, dalam upaya peningkatan disiplin pegawai maka telah dikeluarkan Perbup N0 46 Tahun 2013 yang mengatur jam kerja dan konsekuensinya terkait dengan pemotongan Tambahan Penghasilan (TPP)-nya. Adanya Perbup 46/2013 tentang Disiplin Pegawai, PNS Kukar wajib absen 4 kali tiap hari, yakni saat masuk kerja, keluar istirahat, masuk setelah istirahat dan pada saat pulang dan ini diterapkan efektif sejak November 2013. Di tahun 2013 sejak diberlakukannya Perbup ini, Kabag Humas dan Protocol Setkab Kukar menyatakan sejak diterapkan pengisian absen hingga 4 kali dengan menggunakan mesin elektronik, tingkat kedisiplinan dan kehadiran pegawai lebih tinggi ${ }^{11}$. Pemberian kenaikan TPP dilakukan Pemkab Kukar untuk meningkatkan kesejahteraan PNS dengan penegakan disiplin kerja. Penekanan pada 
kehadiran/keikutsertaan pada apel pagi ditegaskan Sekkab Kukar dan berimplikasi pada pemotongan TPP bagi pegawai yang melanggar.

Di tahun 2013, BKD membentuk Tim Penegakan Disiplin yang dimaksudkan untuk memperkuat peran pimpinan SKPD terhadap disiplin pegawai. Adanya Tim Penegakan Disiplin ini membantu upaya penegakan disiplin pegawai Kukar. Menurut Kepala BKD, hal ini terbukti dari lebih banyaknya pelaporan dari hasil verifikasi BKD di lapangan dan bukan dari pelaporan SKPD. BKD dan Tim Penanganan Kasus-Kasus Disiplin PNS beberapa kali telah melakukan pemanggilan kepada pegawai dan atasan langsungnya yang melakukan pelanggaran disiplin. Pada Oktober 2013, sebanyak 11 PNS diberhentikan tidak dengan hormat, lima orang pelanggaran disiplin masuk kerja, lima orang terkait narkoba, dan satu orang tersandung korupsi, selain itu 33 PNS yang melakukan pelanggaran disiplin masuk kerja, juga mendapat sanksi-sanksi diantaranya sanksi penurunan pangkat setingkat lebih rendah selama setahun, sanksi penundaan kenaikan gaji berkala, delapan orang mendapat pernyataan tidak puas dari atasan, dua orang ditegur secara tertulis dan 19 orang terkena teguran lisan. Pada Desember 2014, sebanyak delapan PNS dijatuhi sanksi hukuman berat, yakni empat orang mendapat pemberhentian dengan hormat tidak atas permintaan sendiri, dua orang dengan penurunan pangkat setingkat lebih rendah selama tiga tahun, dua orang dibebaskan dari jabatan dan dipindahkan serta satu orang usul pensiun karena uzur/sakit. Pada September 2014, delapan orang dikenakan sanksi hukuman disiplin berat yaitu diberhentikan dengan hormat dikarenakan tidak masuk kerja dan tidak mentaati ketentuan jam kerja, satu orang dilakukan konselling/pembinaan kepada yang bersangkutan, satu orang masih dikoordinasi dengan Inspektorat dan
SKPD yang bersangkutan tentang keberadaannya. Awal Februari 2015, pemanggilan kepada 12 PNS dan pemberian sanksi disiplin berupa pemberhentian dengan hormat, pemberhentian sementara, pembebasan dari jabatan, penurunan pangkat setingkat lebih rendah selama 3 tahun dan selama 1 tahun, dan penundaan kenaikan pangkat selama 1 tahun juga dilakukan. BKD Kukar juga menyebutkan ada 20 PNS dihentikan akibat tidak disiplin selama 2014. PNS yang dipecat mayoritas karena kasus bolos kerja lebih dari 46 hari dalam setahun, bahkan hingga satu tahun, sedangkan empat PNS lainnya disanksi pemberhentian sementara, satu orang pembebasan jabatan dan 13 orang penurunan pangkat setingkat lebih rendah selama 3 tahun,

Sesuai PP 53/2010, tujuan dari sanksi / hukuman disiplin adalah untuk ketertiban dan kelancaran pelaksanaan tugas pokok dan fungsi Pegawai Negeri Sipil, mendorong peningkatan kinerja dan perubahan sikap dan perilaku serta tanggung jawab Pegawai Negeri Sipil. Ancaman sanksi administrasi hingga pemberhentian dengan tidak hormat sudah semakin tegas dilakukan, baik terhadap pelanggaran ringan hingga pelanggaran berat. Menurut Sekretaris $\mathrm{BKD}$, kasus pelanggaran disiplin PNS yang terjadi di Kukar selain berhubungan dengan pekerjaan kantor, juga pelanggaran disiplin yang berkaitan dengan urusan rumah tangga seperti perceraian, dan untuk pelanggaran berat seperti mangkir dari tugas yang banyak terjadi pada pegawai yang bertugas di kecamatan dan kelurahan, terlebih setelah adanya kebijakan pemerataan atau pendistribusian PNS ke kecamatan dan kelurahan terpencil.

Peningkatan upaya penegakan disiplin juga dilakukan melalui penerapan presensi fingerprint dengan system online. Namun, dari hasil uji coba di lima 
SKPD di lingkungan Pemkab Kukar melalui system upload dan share ternyata masih ada SKPD yang tidak mengupload presensi-nya. Keengganan ini menurut Kepala BKD disebabkan karena SKPD lebih "menyukai" metode manual (terutama Kepala SKPD), dan adanya kesan bahwa atasan melindungi bawahan dikarenakan kendala pribadi yang dimiliki pegawai (seperti mengantar anak sekolah terlebih dahulu, dan lain-lain), dan anggapan daftar presensi hanya digunakan untuk mengambil TPP.

Hasil kuisioner dari aspek ketentuan jam kerja terhadap pejabat struktural di Kukar menyatakan bahwa untuk pimpinan dan SKPD 97,98 persen menegakkan aturan disiplin mengenai jam kerja, namun 62 persen pimpinan ini mengakui bahwa meskipun bawahan mereka setiap harinya selalu datang tepat waktu, namun sekitar 38 persen dari responden/pimpinan ini mengatakan bahwa bawahan mereka kadang-kadang saja hadir tepat waktu dikantor. Kondisi ini tentu relatif menggambarkan bahwa dibeberapa SKPD, penegakan kedisiplinan terkait aturan jam kerja optimal pada tataran struktural, namun relatif masih belum maksimal dilaksanakan hingga ke level bawah.

Hal menarik terlihat pada jawaban atas pertanyaan 4 dan pertanyaan 5 pada Gambar 3, dimana baik pejabat struktural maupun bawahan kadang-kadang menggunakan jam kerja untuk keperluan/ urusan pribadi dengan persentase mencapai $54,08 \%$ dan $78 \%$. Kondisi ini juga terkait dengan pertanyaan 7 , dimana bawahan mereka juga kadang-kadang pulang sebelum waktu jam kerja selesai (57\%). Hal ini tentu masih dapat dipahami atau ditolerir pada kondisi dan waktu tertentu, dimana aparatur dapat menggunakan mekanisme atau prosedur izin kepada atasan jika hendak melakukan urusan tertentu diluar kedinasan pada saat jam kerja. Namun, dari sisi intensitasnya perlu mendapatkan perhatian khusus agar kinerja pelayanan dan sistem kerja tidak terganggu.

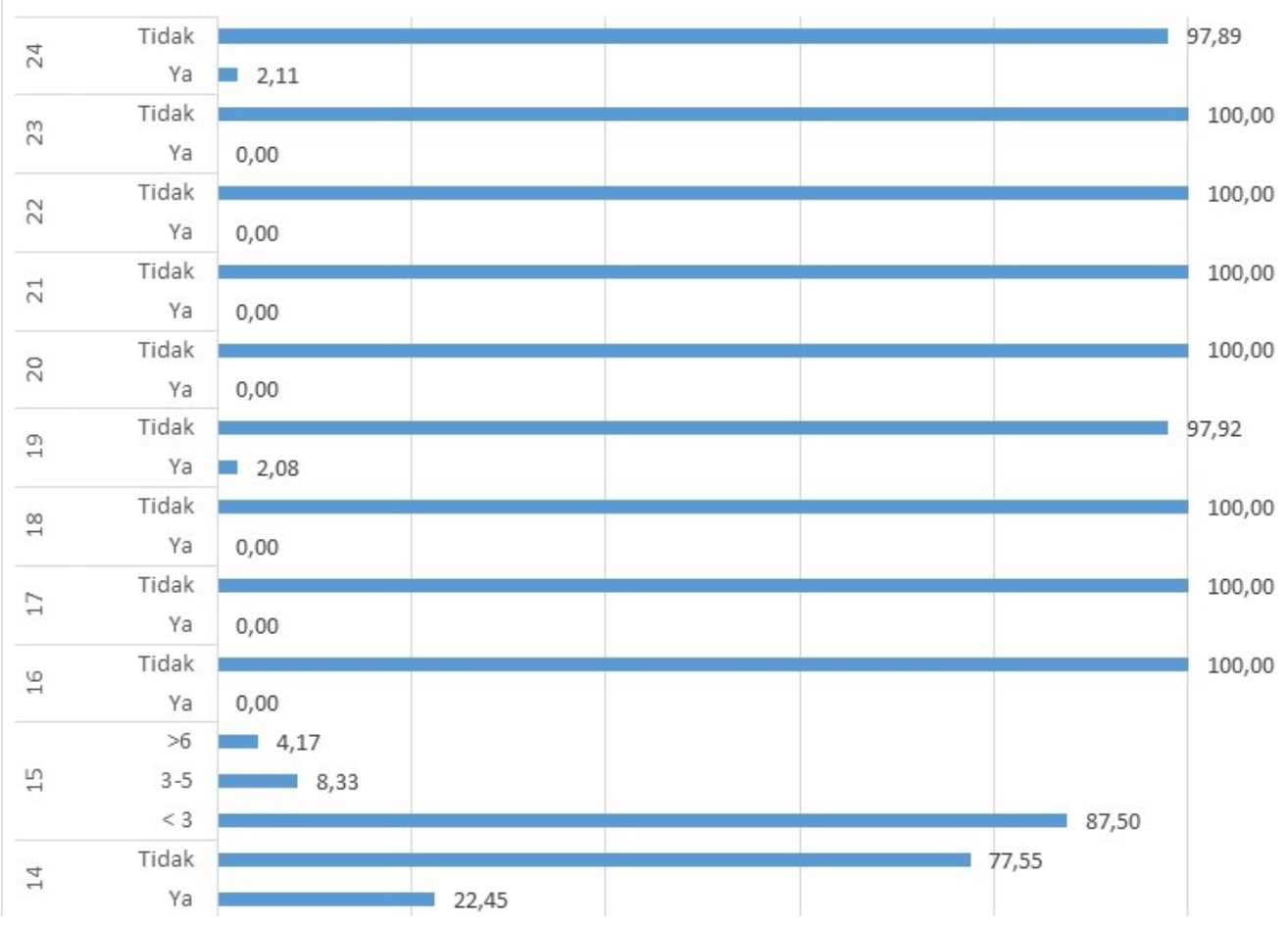




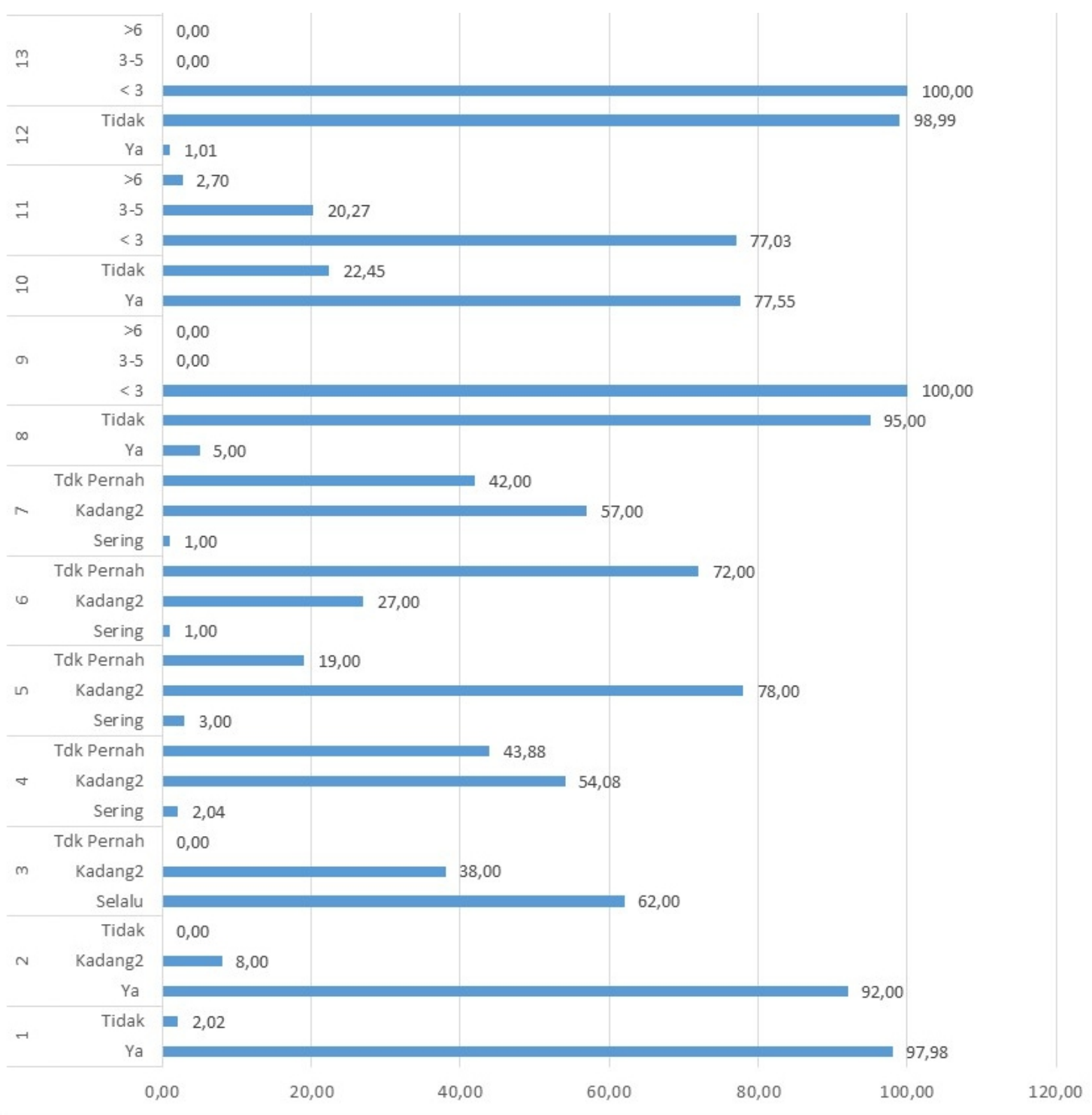

Gambar 3. Rekapitulasi Jawaban Responden Terhadap 24 Pertanyaan Pada Aspek Ketentuan Jam Kerja

Terhadap pelanggaran ketentuan jam kerja (pertanyaan $8,12,16,18$, dan 20), secara umum pada level struktural belum pernah melakukan pelanggaran ketentuan jam kerja sehingga relatif sebagian besar pejabat yang ada belum pernah mendapatkan hukuman kedisiplinan baik yang berupa teguran lisan, teguran tertulis, sanksi penundaan kenaikan gaji berkala, maupun sanksi penundaan kenaikan pangkat. Fakta ini cukup menggembirakan karena posisi pejabat struktural yang perlu menjadi teladan dan panutan bagi pegawai yang ada sehingga unsur kedisiplinan pimpinan menjadi tolok ukur bagi pegawai untuk juga mereplikasi unsur kedisiplinan tersebut dalam lingkungan dan pola kerjanya.

Pada tingkat jabatan fungsional, pelanggaran ketentuan jam kerja (pertanyaan 10, 14, 17, 19, 22, dan 24) dominan hanya sampai pada pemberian teguran lisan dan cenderung bawahan yang diberikan teguran lisan tersebut segera memperbaiki kesalahannya. Adapun hukuman kedisiplinan akibat pelanggaran ketentuan jam kerja lainnya 
seperti teguran tertulis, sanksi penundaan kenaikan gaji berkala, maupun sanksi penundaan kenaikan pangkat, penurunan pangkat, hingga sanksi diberhentikan sebagai PNS jumlahnya relatif sangat sedikit dan terjadi pada SKPD-SKPD tertentu saja. Menurut Kepala BKD, di tahun 2012-2014 (selama dua tahun), Pemkab telah memberhentikan 30 pegawainya dengan berbagai pelanggaran, seperti dua tahun tidak pernah masuk kerja, dan terkena kasus narkoba. Implementasi penegakan disiplin ini yang dilakukan bahkan dengan memberhentikan gaji terlebih dahulu, agar pegawai tersebut datang ke kantor. Penegakan disiplin untuk ringan hingga sedang diserahkan kepada SKPD yang bersangkutan, namun untuk pelanggaran berat barulah ditangani oleh BKD.

Pada aspek pemahaman terkait regulasi kedisiplinan, rekapitulasi jawaban pejabat struktural terkait aspek regulasi kedisiplinan terlihat pada Gambar 4 dimana seluruh pejabat struktural (96,91\%) telah mengetahui adanya peraturan kedisiplinan yang ada (PP No. 53 Tahun 2010 dan Perbup No. 46 Tahun 2013) pada pertanyaan 49, telah membaca dan mengerti kandungan dari regulasi kedisiplinan tersebut $(89,69 \%)$ pada pertanyaan 50 , juga sudah pernah mengikuti sosialisasi terkait peraturan mengenai kedisiplinan tersebut $(97,85 \%)$ pada pertanyaan 51. Dengan demikian dapat dipahami bahwa pada level s truktural le bi h m a m pu mengimplementasikan peraturan kedisiplinan dilingkungan kerjanya masing-masing dan menularkan pemahaman terkait regulasi tersebut secara utuh kepada seluruh pegawai di level SKPD-nya masing-masing.

Berdasarkan Gambar 4, juga dapat diketahui (pertanyaan 51 hingga pertanyaan 69) bahwa pemahaman terhadap larangan-larangan dalam aturan kedisiplinan telah secara dominan diketahui dan dipahami oleh sebagian besar pejabat struktural di lingkungan Pemerintah Kabupaten Kutai Kartanegara. Pemahaman atas laranganlarangan tersebut yaitu,

- Larangan penyalahgunaan wewenangan atau kekuasaan dan mengetahui sanksi yang diberikan $(97,85 \%)$;

-Larangan menawarkan menjadi perantara untuk mendapatkan keuntungan pribadi dengan menggunakan kewenangan orang lain $(85,57 \%)$;

- Larangan memiliki, menjual, membeli, menggadaikan, menyewakan, atau meminjamkan barang-barang baik bergerak atau tidak bergerak, dokumen atau surat berharga milik negara/ daerah secara tidak sah $(89,47 \%)$;

- Larangan melakukan kegiatan bersama dengan atasan, teman sejawat, bawahan, atau orang lain di dalam maupun diluar lingkungan kerjanya dengan tujuan untuk keuntungan pribadi, golongan, atau pihak lain, yang secara langsung atau tidak langsung merugikan negara $(88,66 \%)$;

- Larangan memberi atau menyanggupi akan memberi sesuatu kepada siapapun baik secara langsung atau tidak langsung dan dengan dalih apapun untuk diangkat dalam jabatan $(89,69 \%)$;

- Larangan menerima hadiah atau suatu pemberian apa saja dari siapapun juga yang berhubungan dengan jabatan dan/atau pekerjaannya $(93,88 \%)$;

- Larangan bertindak sewenang-wenang terhadap bawahan $(69,39 \%)$;

- Larangan melakukan suatu tindakan atau tidak melakukan suatu tindakan yang dapat menghalangi atau mempersulit salah satu pihak yang dilayani sehingga mengakibatkan kerugian bagi yang dilayani $(68,75 \%)$; serta

- Larangan menghalangi berjalannya tugas kedinasan $(69,79 \%)$. 
Implementasi Peraturan Pemerintah Nomor 53 Tahun 2010 Tentang Disiplin

Pegawai Khususnya Aspek Jam Kerja di Kabupaten Kutai Kartanegara

Wildan Lutfi A dan Mayahayati K.

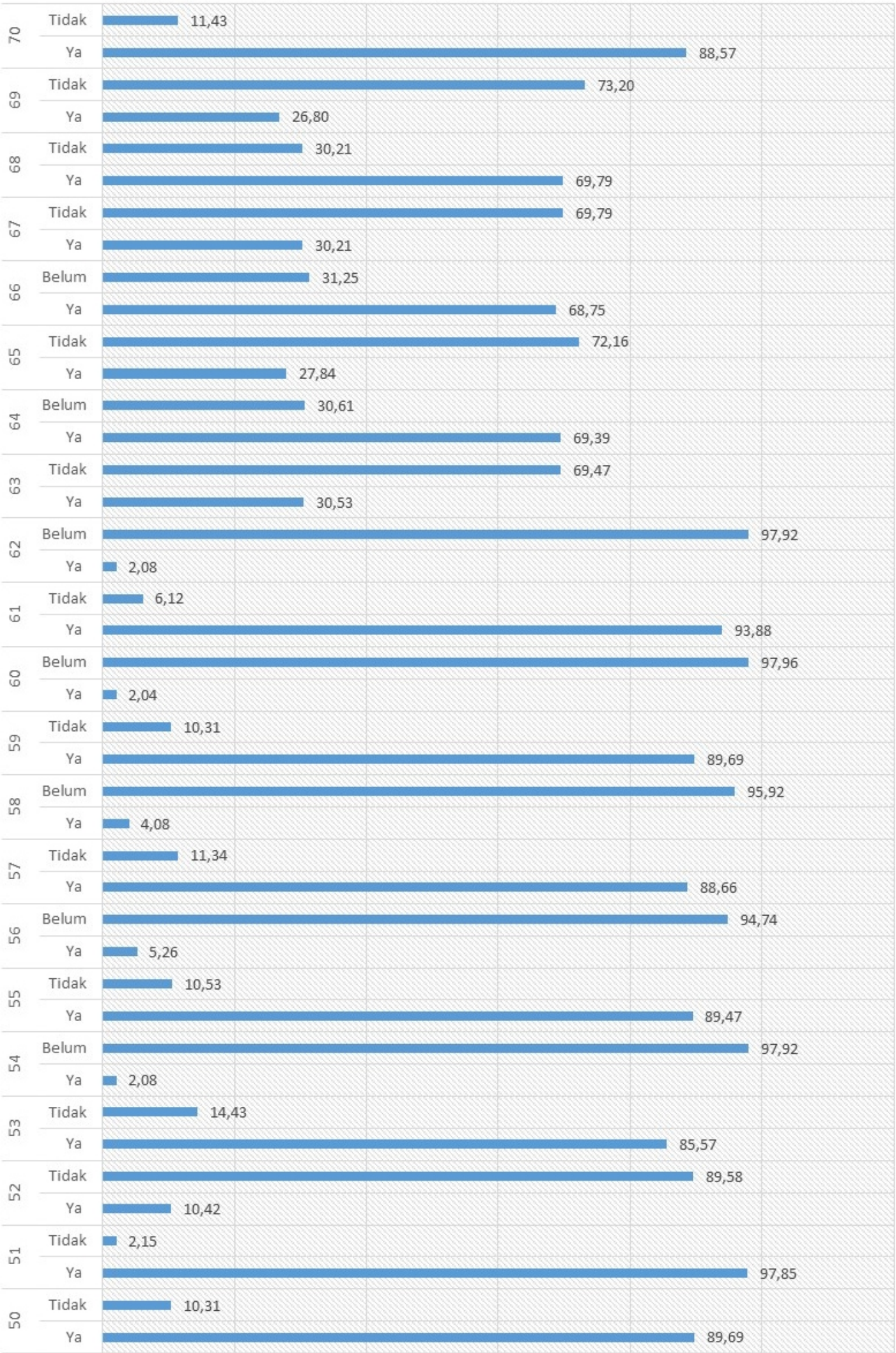




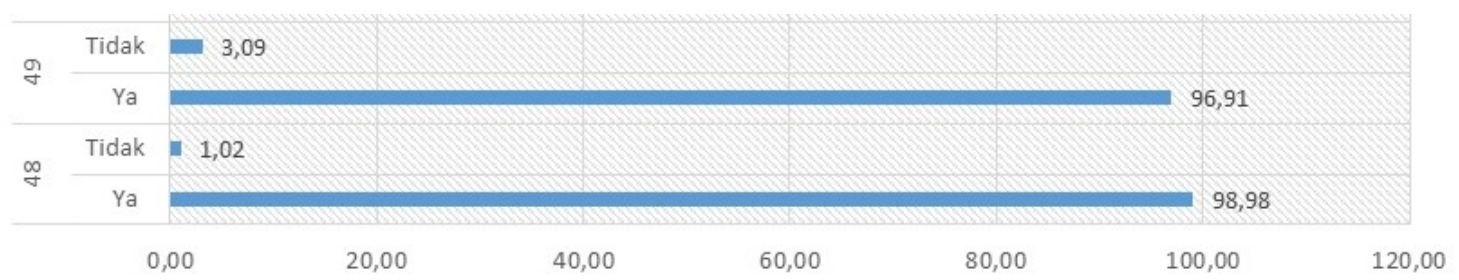

Gambar 4. Rekapitulasi Jawaban Responden Terhadap Pertanyaan pada Aspek Pemahaman Terkait Regulasi Kedisiplinan

Kasus-kasus terkait pelanggaran atas larangan-larangan dalam aturan kedisiplinan oleh responden relatif dijawab belum pernah terjadi di SKPDnya. Meskipun demikian, pada beberapa SKPD tertentu kasus-kasus terhadap pelanggaran kedisiplinan tersebut masih terjadi, seperti kasus pejabat/ pegawai menerima hadiah atau suatu pemberian apa saja dari siapapun juga yang berhubungan dengan jabatan dan/atau pekerjaannya $(30,53 \%)$; kasus pejabat yang bertindak sewenang-wenang terhadap bawahan $(27,84 \%)$; juga kasus pejabat yang melakukan suatu tindakan atau tidak melakukan suatu tindakan yang dapat menghalangi atau mempersulit salah satu pihak yang dilayani sehingga mengakibatkan kerugian bagi yang dilayani $(30,21 \%)$. Berdasarkan hal ini, penguatan-penguatan sosialisasi terkait larangan-larangan dalam aturan kedisiplinan, pengawasan, maupun pembinaan perlu digiatkan agar kasuskasus pelanggaran kedisiplinan dapat diminimalisir jumlahnya disamping untuk memperkuat komitmen bersama dalam mewujudkan pemerintahan yang berdisiplin tinggi dan berkinerja tinggi.

Dilihat dari keterkaitan antara Tambahan Penghasilan PNS (TPP) dengan peningkatan kedisiplinan PNS di lingkungan Pemerintah Kabupaten Kutai Kartanegara (pertanyaan 70) ditanggapi oleh sebagian besar pejabat struktural $(88,57 \%)$ memiliki keterkaitan yang sangat erat. Pengaruh TPP ini memang diyakini sebagai upaya instan untuk mendorong peningkatan kedisiplinan dan kinerja pegawai, meskipun diharapkan secara kontinu sistem kedisiplinan ditingkat SKPD masing-masing dapat berjalan. Dengan ini diharapkan kesadaran berperilaku dan bertindak disiplin dapat menjadi budaya aparatur di lingkungan Pemerintah Kabupaten Kutai Kartanegara. Implikasi TPP terhadap peningkatan kedisiplinan dan kinerja pegawai menurut Kepala BKD menjadi momentum yang berkaitan dengan tanggung jawab fnansial, dan sekarang juga diikuti dengan pelaporan kinerja. Jika ini bisa terlaksana maka TPP selanjutnya akan menjadi faktor pendukung saja.

Berdasarkan hasil rekapitulasi jawaban responden jabatan fungsional sebagaimana disajikan pada Gambar 5, menunjukkan bahwa pegawai sudah mengetahui adanya ketentuan jam kerja di SKPD-nya masing-masing (pertanyaan 1). SKPD tempat bertugas sebagian besar juga sangat menegakkan aturan disiplin terkait aturan jam kerja (pertanyaan 2). Adapun pertanyaan 3, sebagian besar responden $(75,74 \%)$ menganggap bahwa mereka setiap harinya selalu datang ke kantor tepat waktu, meskipun sekitar $23,67 \%$ responden lainnya mengatakan kadang-kadang. Dari hasil ini, upaya penguatan penegakan aturan jam kerja masih perlu dilaksanakan oleh masingmasing SKPD, sehingga diharapkan seluruh pegawai dapat hadir tepat waktu untuk menjalankan tugasnya dan memberikan pelayanan kepada publik 
secara on time pula.

Terkait penggunaan jam kerja untuk keperluan/ urusan pribadi (pertanyaan 4) sebagian besar responden $(66,08 \%)$ mengakui bahwa mereka kadang-kadang menggunakan jam dinas untuk melakukan pengurusan keperluan pribadi. Hasil ini sangat berkorelasi dengan pendapat pada kelompok jabatan struktural yang sebagian besar juga mengakui kondisi ini. Tidak dapat dipungkiri bahwa aparatur dapat dan diperbolehkan untuk menggunakan jam kerja untuk melakukan pengurusan keperluan pribadi dengan catatan mendapatkan persetujuan atasannya dan telah menyelesaikan tugas-tugas yang diberikan. Di sisi lain, intensitas aparatur menggunakan jam kerja untuk urusan pribadi juga perlu dibatasi agar tidak menjadi kebiasaan. Disini diperlukan ketegasan dan juga penguatan sistem kedisiplinan SKPD yang berlaku secara merata baik kepada pejabat struktural maupun jabatan fungsional umum.

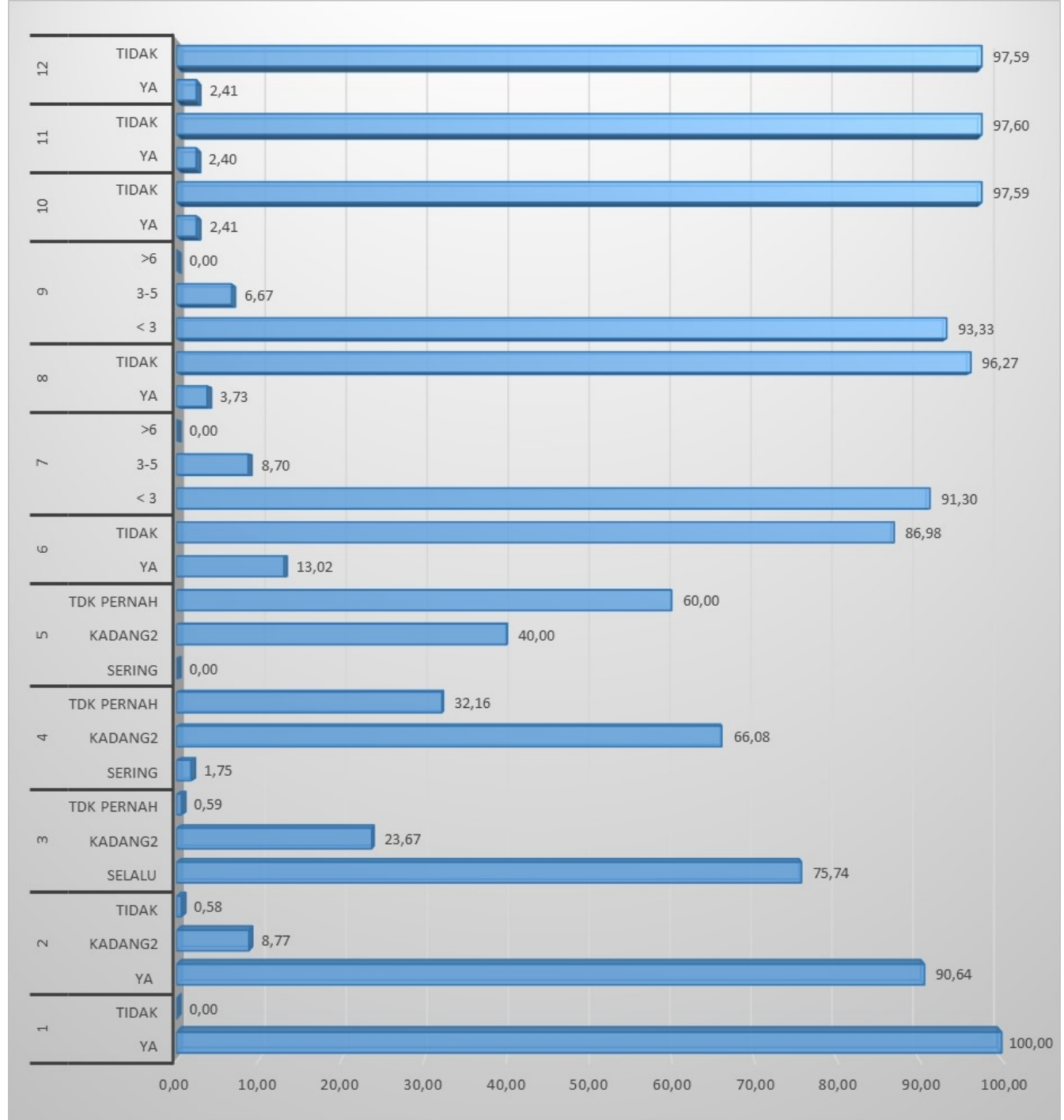

Gambar 5. Rekapitulasi Jawaban Responden Terhadap 12 Pertanyaan Pada Aspek Ketentuan Jam Kerja 
Pelanggaran kedisiplinan khususnya pada ketentuan jam kerja sebagaimana diungkap pada Gambar 5, pertanyaan 5 hingga pertanyaan 12 menunjukkan hasil yang cukup baik, dimana sebagian besar responden mengatakan bahwa mereka senantiasa disiplin. Pegawai pulang ketika waktu jam kerja selesai $(60 \%)$, tidak pernah mendapatkan teguran lisan dari atasan karena melanggar ketentuan jam kerja $(86,98 \%)$, tidak pernah mendapatkan teguran tertulis karena melanggar ketentuan jam kerja (96,27\%), tidak pernah mendapatkan sanksi penundaan kenaikan gaji berkala $(97,59 \%)$, tidak pernah mendapatkan sanksi penundaan kenaikan pangkat $(97,60 \%)$, dan tidak pernah mendapatkan sanksi penurunan pangkat $(97,59 \%)$. Tingkat kedisiplinan ini tentu perlu dimonitor secara berkesinambungan dan menjadi salah satu faktor penilaian perilaku pegawai.

Dari aspek pemahaman terkait regulasi kedisiplinan, berdasarkan Gambar 6 dapat disimpulkan bahwa secara umum para pejabat fungsional telah mengetahui dan memahami peraturan yang terkait kedisiplinan (PP No. 53 Tahun 2010 dan Perbup No. 46 Tahun 2013). Pegawai juga telah membaca dan mengerti regulasi tersebut (pertanyaan 37 dan 38) dan telah mengikuti sosialisasi terkait penerapan peraturan tentang kedisiplinan tersebut (pertanyaan 39). Akibat pemahaman dan pengetahuan terkait aturan tersebut, para pejabat fungsional juga telah mengetahui tingkatan sanksi terhadap pelanggaran hukuman disiplin yang dilakukan (pertanyaan 40). Kondisi ini menunjukkan bahwa relatif aturan kedisiplinan telah merata disosialisasikan kepada seluruh aparatur di lingkungan Pemerintah Kabupaten Kutai Kartanegara, konsekuensi lainnya adalah aparatur perlu mengimplementasikannya secara tertib aturan tersebut dan menyadari implikasi dibalik pelanggaran atas aturan kedisiplinan tersebut. Di samping itu, diharapkan dengan dipahaminya regulasi ini tingkat kehadiran dan kinerja pegawai dapat meningkat signifikan.

Terkait larangan dalam aturan kedisiplinan (pertanyaan 41 sampai dengan 55), relatif secara umum para pejabat fungsional telah mengetahui dan memahami jenis-jenis larangan dalam regulasi tersebut. Adapun laranganlarangan tersebut adalah:

- Larangan penyalahgunaan wewenangan atau kekuasaan dan mengetahui sanksi yang diberikan $(91,52 \%)$;

-Larangan menawarkan menjadi perantara untuk mendapatkan keuntungan pribadi dengan menggunakan kewenangan orang lain $(86,06 \%)$;

- Larangan melakukan kegiatan bersama dengan atasan, teman sejawat, bawahan, atau orang lain di dalam maupun diluar lingkungan kerjanya dengan tujuan untuk keuntungan pribadi, golongan, atau pihak lain, yang secara langsung atau tidak langsung merugikan negara $(93,83 \%)$;

- Larangan memberi atau menyanggupi akan memberi sesuatu kepada siapapun baik secara langsung atau tidak langsung dan dengan dalih apapun untuk diangkat dalam jabatan (91,41\%);

- Larangan menerima hadiah atau suatu pemberian apa saja dari siapapun juga yang berhubungan dengan jabatan dan/atau pekerjaannya $(93,90 \%)$;

- Larangan bertindak sewenang-wenang terhadap bawahan $(95,63 \%)$;

- Larangan melakukan suatu tindakan atau tidak melakukan suatu tindakan yang dapat menghalangi atau mempersulit salah satu pihak yang dilayani sehingga mengakibatkan kerugian bagi yang dilayani $(95,68 \%)$; serta

- Larangan menghalangi berjalannya 
tugas kedinasan $(94,55 \%)$.

Kasus-kasus terkait pelanggaran atas larangan-larangan dalam aturan kedisiplinan tersebut pun relatif sebagian besar responden mengatakan belum pernah terjadi di SKPD-nya. Namun demikian, upaya pembinaan, dan sosialisasi kepada seluruh pegawai dalam
SKPD perlu terus digalakkan agar kasuskasus pelanggaran kedisiplinan dapat diminimalisir. Disamping itu, pembangunan dan pengembangan sistem dan budaya disiplin perlu dilaksanakan secara terus menerus.

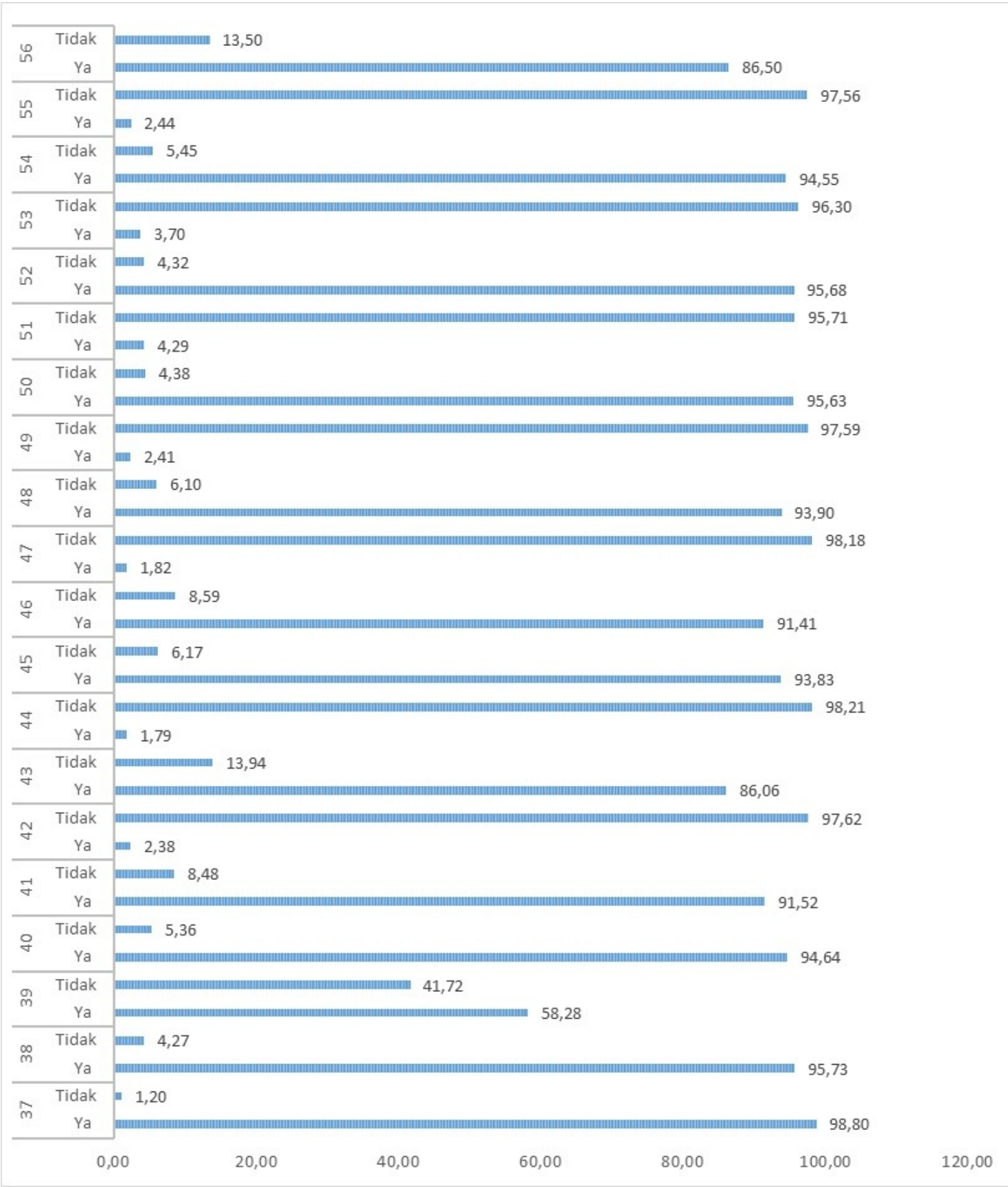

Gambar 6. Rekapitulasi Jawaban Responden Terhadap Pertanyaan pada Aspek Pemahaman Terkait Regulasi Kedisiplinan 
Pada aspek yang lain, juga diperoleh gambaran persepsi pejabat fungsional (pertanyaan 56) yang secara umum mengatakan bahwa terdapat keterkaitan yang cukup tinggi antara Tambahan Penghasilan PNS (TPP) dengan peningkatan disiplin PNS di lingkungan Pemerintah Kabupaten Kutai Kartanegara $(86,50 \%)$.Pemotongan terhadap TPP jika aparatur tidak mengisi daftar kehadiran menjadi alasan utama bagi sebagian besar pegawai untuk secara rutin datang ke kantor dan pulang kerja tepat waktu.TPP saat ini masih cenderung dipandang sebagai instrumen yang cukup ampuh untuk mendorong pegawai taat pada aturan dan secara instan memperbaiki kinerja pelayanan publik, namun perlu dipertimbangkan upaya lain yang dapat menanamkan kebiasaan disiplin dalam pribadi pegawai seperti, keteladanan pimpinan, award bagi pegawai yang memiliki disiplin tinggi, menjadikan unsur disiplin sebagai syarat promosi, dan lain-lain.

Selain jumlah pegawai yang sangat banyak, masalah yang dihadapi dalam penegakan disiplin di Kukar ini berasal dari tiga faktor, yaitu pegawai, pimpinan SKPD serta sistem penegakan disiplin.

\section{Faktor pegawai}

Dari hasil wawancara dengan pimpinan BKD diketahui bahwa selama ini ada kebiasan salah, yang dimiliki oleh beberapa pegawai terkait dengan jam kerja, yang mempengaruhi kedisiplinan di lingkungan kerja mereka. Mind set sebagian pegawai menganggap bahwa tidak masuk kerja adalah hal yang biasa, sehingga dilapangan ditemukan ada pegawai yang dua tahun, bahkan ada yang sampai empat tahun tidak masuk kerja. Selain itu banyak juga pegawai yang resisten terhadap aturan terkait dengan disiplin. Kondisi ini tergambar ketika mulai diberlakukannya absen menggunakan finger print, masih terdapat pegawai yang mencoba merubah data, dengan tujuan TPP yang mereka dapatkan tidak dipotong, sebagaimana yang diatur dalam Peraturan Bupati.

2. Faktor pimpinan

Sebagaimana yang dijelaskan oleh Hasibuan (dalam Elvira 2014), dalam sebuah kepemimpinan melekat fungsi pengawasan yang bertujuan untuk mewujudkan kedisiplinan pegawai. Dengan pengawasan melekat, pimpinan secara langsung harus mengawasi kinerja maupun perilaku bawahannya. Terkait dengan faktor pengawasan, menurut pimpinan BKD dalam wawancara adalah,kurang pembinaan dari pimpinan. Padahal penekanan PP 53/2010 sudah jelas bahwa jika pegawai yang melakukan pelanggaran disiplin tidak dihukum, maka pimpinannya yang akan dihukum. Kurangnya pembinaan dari pimpinan ini tergambar dari masih adanya pimpinan SKPD yang tidak melaporkan atau memberikan teguran kepada pegawainya yang tidak hadir tanpa keterangan dalam waktu yang lama. Pimpinan SKPD masih merasa itu bukan kewajiban mereka, dan menyerahkannya kepada BKD. Selain itu, unsur kekerabatan di pemerintah Kabupaten Kutai Kartanegara juga masih tinggi, sehingga terkadang pimpinan tidak bisa melakukan penegakkan disiplin kepada pegawainya yang melanggar disiplin kerja. Masalah selanjutnya adalah, masih ada sebagian pimpinan SKPD yang belum memiliki komitmen terhadap penegakan disiplin di lingkungan kerjanya. Hal tersebut terlihat dari keengganan SKPD untuk menggunakan sistem presensi finger print dengan sistem online, yang mulai digalakkan oleh BKD.Padahal 
tujuan BKD menggunakan sistem presensi finger print adalah agar pemberian TPP kepada pegawai disesuaikan dengan kehadiran mereka, sehingga setidaknya kedepan pegawai akan disiplin masalah jam kerja.

3. Faktor Sistem Penegakan Disiplin

Dengan jumlah pegawai yang relatif besar, sangat diperlukan sistem dalam penegakan disiplin di Lingkungan Pemerintah Kabupaten Kutai Kartanegara. Seperti yang disampaikan oleh Herry Indrawan (2008) peraturan atau tata tertib merupakan salah satu faktor pembentuk kedisiplinan. Namun untuk mengefektifkan peraturan atau tata tertib yang sudah ada, diperlukan sebuah sistem yang jelas. Saat ini BKD sudah memiliki kebijakan terkait presensi finger print dengan sistem online. Dengan sistem ini sebenarnya surat teguran bagi pegawai yang tidak masuk kerja tanpa keterangan selama lima hari berturutturut langsung bisa diprint secara otomatis, namun kendalanya mesin finger print yang ada di setiap SKPD berbeda-beda spesifikasinya, sehingga sistem presensi ini tidak dapat berjalan maksimal. Selain itu ketidakefektifan sistem presensi ini adalah belum adanya pengupload data absen di beberapa SKPD, serta belum diterapkannya sangsi terhadap SKPD yang tidak menggunakan sistem presensi ini, penegakan disiplin tidak dapat secara merata dipantau dan dilakukan disemua SKPD.

\section{Strategi Implementasi PP 53 Tahun 2010 di lingkungan Pemerintah Kabupaten Kutai Kartanegara}

Implementasi PP 53 Tahun 2010 tentang Disiplin PNS telah ditindaklanjuti pemerintah Kabupaten Kutai Kartanegara dengan menerbitkan Peraturan Bupati No 46 Tahun 2013 tentang Penegakan Disiplin PNS di lingkungan Kabupaten Kutai Kartanegara. Pada aspek ketentuan jam kerja perlu diambil alternatif tindakan penguatan dengan meningkatkan prosedur pengelolaan ijin pada saat jam kerja. Perlu ada kejelasan mengenai perihal ijin, waktu dan klasifikasi kepentingan ijin jam kerja yang dapat ditoleransi. Meskipun hal ini tidak dimaksudkan untuk membuka ruang ijin menjadi lebih fleksibel. Hal selanjutnya yang perlu diambil alternatif tindakan penguatan adalah membangun sistem peningkatan kinerja sehingga penggunaan jam kerja dapat terkontrol. Hal ini perlu dilakukan untuk memastikan bahwa ada progress atau output yang dihasilkan pegawai dalam rentang waktu tertentu. Pemberian ijin pada saat jam kerja dapat ditoleransi dengan konsekuensi output dari pekerjaan pegawai dalam rentang waktu tertentu dapat di selesaikan dengan baik.

Pada aspek pemahaman regulasi kedisiplinan, hampir semua pegawai telah memiliki pemahaman yang cukup mengenai regulasi kedisiplinan dan bentuk pelanggaran atas larangan dalam aturan kedisiplinan belum pernah terjadi di SKPD. 
Tabel 3. Alternatif Tindakan Penguatan Implementasi Peraturan Pemerintah Nomor 53

Tahun 2010 di Lingkungan Kabupaten Kutai Kartanegara

\begin{tabular}{|c|c|c|c|c|}
\hline No & Aspek & $\begin{array}{c}\text { Persepsi Pejabat } \\
\text { Struktural }\end{array}$ & $\begin{array}{c}\text { Persepsi Pejabat } \\
\text { Fungsional }\end{array}$ & $\begin{array}{c}\text { Alternatif Tindakan } \\
\text { Penguatan }\end{array}$ \\
\hline 1 & $\begin{array}{l}\text { Ketentuan Jam } \\
\text { Kerja }\end{array}$ & $\begin{array}{l}\text { Penegakan disiplin } \\
\text { terkait jam kerja optimal } \\
\text { pada tataran struktural, } \\
\text { namun relative masih } \\
\text { belum maksimal } \\
\text { dilaksanakan hingga } \\
\text { level staff }\end{array}$ & $\begin{array}{l}\text { Sebagian mengakui } \\
\text { kadang - kadang } \\
\text { menggunakan jam } \\
d i n \text { a } \mathrm{u} n \mathrm{n} \text { u } k \\
\text { keperluan pribadi }\end{array}$ & $\begin{array}{l}\text { Pengelolaan prosedur } \\
\text { ijin pada saat jam } \\
\text { dinas } \\
\text { Perlu ditingkatkan dan } \\
\text { membangun sistem } \\
\text { peningkatan kinerja } \\
\text { sehingga penggunaan } \\
\text { jam dinas dapat } \\
\text { terkontrol }\end{array}$ \\
\hline 2 & $\begin{array}{l}\text { Pemahaman } \\
\text { Regulasi } \\
\text { Kedisiplinan }\end{array}$ & $\begin{array}{l}\text { Relatif Telah memiliki } \\
\text { pemahaman yang cukup } \\
\text { mengenai regulasi } \\
\text { kedisiplinan }\end{array}$ & $\begin{array}{l}\text { Relatif kasus atas } \\
\text { larangan-larangan } \\
\text { dalam aturan } \\
\text { kedisiplinan belum } \\
\text { pernah terjadi di } \\
\text { SKPD }\end{array}$ & $\begin{array}{l}\text { Memaksimalkan } \\
\text { sistem pengawasan } \\
\text { regulasi dengan } \\
\text { membuat laporan } \\
\text { progress manajemen } \\
\text { perubahan di SKPD }\end{array}$ \\
\hline
\end{tabular}

Sebagai langkah alternatif tindakan penguatan yang perlu dilakukan adalah memaksimalkan sistem pengawasan regulasi dengan membuat laporan progress manajemen perubahan di SKPD. Hal ini perlu dilakukan sehingga proses duplikasi budaya kerja yang baik dapat terkontrol dan dievaluasi pencapaiannya. Pekerjaan merubah budaya kerja yang biasa menjadi luar biasa memerlukan usaha besar dan tindakan nyata dalam kesehariannya. Sekiranya metode pengawasan regulasi ini dapat menjadi basis untuk melakukan perubahan besar mind setpegawai terkait kedisiplinan.

\section{A. PENUTUP \\ Kesimpulan}

Diterbitkannya Peraturan Bupati No 46 Tahun 2013 tentang Penegakan Disiplin PNS dalam rangka pelaksanaan reformasi birokrasi, penegakan disiplin, mendorong profesionalisme dan meningkatkan kinerja PNS di Kukar. Kondisi ini menjadi faktor penting dalam rangka penegakan disiplin di Kukar. Di beberapa SKPD, penegakan kedisiplinan terkait aturan jam kerja, optimal pada tataran struktural, namun relatif masih belum maksimal dilaksanakan hingga ke level bawah. Level struktural lebih mampu mengimplementasikan peraturan kedisiplinan di lingkungan kerjanya masing-masing dan menularkan pemahaman terkait regulasi tersebut secara utuh kepada seluruh pegawai di level SKPD-nya masing-masing. Saat ini, TPP masih dipandang sebagai instrumen yang ampuh untuk mendorong pegawai taat aturan. Pegawai mengatakan bahwa terdapat keterkaitan yang cukup tinggi antara Tambahan Penghasilan PNS (TPP) dengan peningkatan disiplin PNS di lingkungan Pemerintah Kabupaten Kutai Kartanegara.

Faktor penghambat yang paling banyak ditemui di lapangan adalah lebih kepada persepsi sebagian pegawai yang masih resistensi terhadap perubahan mind set yang dilakukan oleh pemerintah kabupaten Kutai Kartanegara terkait dengan kedisiplinan. Belum maksimalnya membangun komitmen di SKPD juga 
perlu menjadi perhatian, sehingga berdampak pada minimnya peran pengawasan pada pimpinan SKPD terhadap kedisiplinan pegawainya.

\section{Rekomendasi}

Kepala Kanreg I B KN menyatakan bahwa salah satu hal penting yang perlu dilakukan penyesuaian dalam UU ASN adalah terkait dengan peraturan disiplin PNS yang harus dapat dipahami dan terimplementasi dengan benar karena substansi disiplin PNS menjadi hal sangat lekat dengan keseharian pegawai dalam bekerja. Menunggu penyesuaian terkait peraturan disiplin selanjutnya, Pemkab Kukar perlu mengintensifkan disiplin pegawai kepada pegawai. Pendekatan yang sebelumnya dengan reward dan punishment, bisa diarahkan pada keikutsertaan PNS dan masyarakat peduli pada kinerja pemerintahannya, PNS dan masyarakat diajak secara persuasif untuk merubah mindset terhadap kedisiplinan. Kepala BKN RI, Bima Haria Wibisana menyatakan bahwa pembinaan terhadap ASN harus lebih diintensifkan agar dapat menekan terjadinya pelanggaran disiplin pegawai, dan pemberian hukuman disiplin harus mengikuti prosedur regulasi kepegawaian yang ada. Dari pernyataan tersebut, disamping penguatan secara formal mengenai jam kerja dan ketentuan disiplin lainnya, perlu menguatkan dan mengubah mindset pegawai serta culture set pemerintah daerah untuk menanamkan sifat profesionalitas. Seharusnya mind set PNS untuk disiplin dalam bekerja (masuk kerja) adalah untuk professional melaksanakan tugas dan fungsinya (apalagi berkaitan dengan UU ASN, ada 3 fungsi ASN, yakni pelaksana kebijakan publik, pelayan publik, perekat dan pemersatu bangsa), TPP hanya merupakan salah satu alat untuk menstimulus pegawai agar tepat waktu datang ke kantor, namun saat ini, banyak pegawai yang mengaitkan bahwa dengan disiplin jam kerja maka kompensasi pada materi berupa TPP yang didapat. Mind set pegawai lebih mengarah pada tunjangan dan pemotongan tunjangan. Disiplin terhadap waktu kerja lebih dikarenakan tunjangan, perlu untuk mengembalikan mind set pegawai bahwa disiplin adalah kewajiban pegawai, dan tunjangan (TPP) sebagai tambahan penghasilan. Sebagaimana yang disampaikan Menteri Pendayagunaan Aparatur Negara dan Reformasi Birokrasi (Menpan-RB) Yuddy Chrisnandi bahwa Aparatur Sipil Negara (ASN) tidak cukup hanya menjadi pegawai disiplin dan mengabdi kepada masyarakat karena masyarakat menuntut agar kinerja ASN lebih baik lagi, sehingga ASN dituntut meningkatkan kapabilitas dan profesionalisme agar harapan dari masyarakat bisa dilayani dengan sebaikbaiknya. Hal lain yang perlu di lakukan adalah dengan mengatur kembali pengelolaan prosedur ijin pada saat jam kerja. Kondisi ini perlu dilakukan karena beberapa persepsi pegawai yang masih ada menggunakan jam kerja untuk keperluan yang bukan kepentingan pekerjaan. Peran atasan langsung akan menjadi penting dengan menempatkan disiplin langsung pada pegawai yang bersangkutan. Beberapa langkah penting yang dapat dilakukan terkait pembentukan lembaga litbang adalah sebagai berikut:

1. Penerapan sistem pengendalian disiplin pegawai perlu dikaitkan dengan sistem manajemen kinerja, sehingga penggunaan jam kerja dapat dioptimalkan bagi pencapaian target kinerja organisasi.

2. Mengatur kembali pengelolaan prosedur ijin pada saat jam kerja. Hal ini perlu dilakukan karena persepsi pegawai yang masih ada menggunakan jam kerja untuk keperluan yang bukan kepentingan pekerjaan. 
3. Peningkatan kapasitas pegawai (perilaku) terkait kejujuran dan integritas.

4. Peningkatan kapasitas (kompetensi) pegawai harus didasarkan pada kebutuhan riil pegawai untuk menunjang kompetensinya.

5. Terkait dengan Tim Reformasi Birokrasi dan Tim Manajemen Perubahan yang telah terbentuk perlu mengoprasionalkan kebijakannya sampai pada level unitkerja.

\section{DAFTAR PUSTAKA}

Elvira, 2014, Pengaruh Efektifitas Penerapan Absensi Elektronik HandkeyTerhadap Disiplin Pegawai di Kantor Loka Monitor Padang, JurnalFakultas Ekonomi Universitas Taman Siswa, Padang.

Isaac and Michael, 1981, Handbook in research and evaluation, New York, Pergamon Press Ltd.

Listyaningsih, Kajian Peningkatan Disiplin Aparatur Pemerintah Provinsi Banten, Program Studi Ilmu Administrasi Negara Fakultas Ilmu Sosial Dan Ilmu Politik Universitas Sultan Ageng Tirtayasa, Jurnal Adminsitrasi
Publik Volume 3 Nomor 1, Juni 2012

Moekijat. 2002. Manajemen Sumber Daya Manusia: Manajemen Kepegawaian. Mandar Maju. Jakarta.

Sastrohadiwiryo, Bejo Siswanto. 2003. Manajemen Tenaga Kerja Indonesia. edisi 2. PT. Bumu Aksara, Jakarta.

Simamora, Henry. 2004. Manajemen Sumber Daya Manusia. Edisi Ke-3. STIE YKPN.

Sutrisno, Edi. 2009. Manajemen Sumber Daya Manusia. Edisi pertama. Jakarta: Kencana Prenada Media Group.

Thahier, Rohana. (2015). Kendala dan Solusi dalam Peningkatan Disiplin Pegawai Negeri Sipil di Sekretariat Daerah Provinsi Sulawesi Barat. Jurnal Administrasi Negara. Volume 21 No 1,April 2015

Wagiarti, Suryani. 2013. Analisis Implementasi PP Nomor 53 Tahun 2010 Tentang Dispilin PNS di Pemerintah Kabupaten Sumbawa Barat. Jakarta. Universitas Terbuka.

Peraturan Pemerintah No. 53 Tahun 2010 Tentang Disiplin Pegawai Negeri Sipil.



